\title{
Managing a New Policy Framework: Paul Volcker, the St. Louis Fed, and the 1979-82 War on Inflation
}

\author{
Kevin L. Kliesen and David C. Wheelock
}

In October 1979, Federal Reserve Chairman Paul Volcker persuaded his Federal Open Market Committee (FOMC) colleagues to adopt a new policy framework that (i) accepted responsibility for controlling inflation and (ii) implemented new operating procedures to control the growth of monetary aggregates in an effort to restore price stability. These moves were strongly supported by monetaristoriented economists, including the leadership and staff of the Federal Reserve Bank of St. Louis. The next three years saw inflation peak and then fall sharply but also two recessions and considerable volatility in interest rates and money supply growth rates. This article reviews the episode through the lens of speeches and FOMC meeting statements of Volcker and St. Louis Fed president Lawrence Roos and articles by Roos's staff. The FOMC adopted monetarist principles to establish the Fed's anti-inflation credibility, but Volcker was willing to accept deviations of money growth from the FOMC's targets, unlike Roos, who viewed the targets as sacrosanct. The FOMC abandoned monetary aggregates in October 1982 but preserved the Fed's commitment to price stability. The episode illustrates how Volcker used a change in operating procedures to alter policy fundamentally and later adapt the procedures to changed circumstances without abandoning the foundational features of the policy. (JEL E42, E52, E58, N22)

Federal Reserve Bank of St. Louis Review, First Quarter 2021, 103(1), pp. 71-97. https://doi.org/10.20955/r.103.71-97

\section{INTRODUCTION}

Paul A. Volcker was confirmed by the United States Senate as the twelfth Chairman of the Board of Governors of the Federal Reserve System on August 6, 1979. Prior to this appointment, Volcker was serving as the president of the Federal Reserve Bank of New York. Although his public service encompassed years before and after his term at the Fed, many believe that Volcker's crowning achievement was leading the Federal Open Market Committee's (FOMC's)

Kevin L. Kliesen is a research officer and business economist and David C. Wheelock is a senior vice president and special policy advisor at the Federal Reserve Bank of St. Louis. Kathryn Bokun provided research assistance. The authors thank Al Gilbert, Rik Hafer, Jack Tatom, and Dan Thornton for helpful comments on an earlier draft of this article.

(c) 2021, Federal Reserve Bank of St. Louis. The views expressed in this article are those of the author(s) and do not necessarily reflect the views of the Federal Reserve System, the Board of Governors, or the regional Federal Reserve Banks. Articles may be reprinted, reproduced, published, distributed, displayed, and transmitted in their entirety if copyright notice, author name(s), and full citation are included. Abstracts, synopses, and other derivative works may be made only with prior written permission of the Federal Reserve Bank of St. Louis. 
successful fight against the Great Inflation. Volcker died on December 8, 2019, at the age of 92. Upon learning of his passing, Federal Reserve Chair Jerome Powell issued a statement noting that Volcker "exemplified the highest ideals-integrity, courage, and a commitment to do what was best for all Americans. His contributions to the nation left a lasting legacy." 1

Volcker was appointed Fed Chairman after a decade of high and rising inflation that was undermining economic stability. Determined to slay inflation once and for all, Volcker pushed the FOMC in October 1979 to adopt new operating procedures to control the growth of monetary aggregates, which he argued was important for bringing down the rate of inflation. The FOMC's acceptance of Volcker's recommendation was widely regarded as a victory for "monetarist" principles espoused by Milton Friedman, Karl Brunner, Allan Meltzer, and many other economists. The Fed's "monetarist experiment" ended in October 1982 when the FOMC largely abandoned the targeting of monetary aggregates, but by that point inflation had already peaked and was trending downward.

The "Volcker disinflation" has been widely studied and discussed, with most of the focus being on the Fed's adoption of new operating procedures in October 1979 and subsequent actions to bring inflation under control. $\underline{2}$ By contrast, this article examines the episode from the perspective of the leadership and economists of the Federal Reserve Bank of St. Louis. The St. Louis Fed had long been known as the "maverick" Bank within the System because its presidents and staff advocated monetarist policy prescriptions and frequently clashed, both privately and publicly, with the Board of Governors, its staff, and a majority of FOMC members. Volcker would later note in an interview that "the thorn in everyone's side for a couple of decades was the St. Louis Reserve Bank. It went off on its own tack very noisily." $\underline{3}$

The FOMC's apparent acceptance of monetarism in October 1979 was widely seen as a victory for the St. Louis Fed. In the words of Anatol (Ted) Balbach, who led the Bank's Research Department at the time, "[T] he greatest achievement of St. Louis, is precisely...that Volcker finally bit the bullet and controlled the money supply." 4 Lawrence Roos, president of the Federal Reserve Bank of St. Louis at the time, heartily approved of the change in operating procedures and publicly praised Volcker's leadership. Roos had been appointed to lead the St. Louis Fed in 1976 upon the resignation of Darryl Francis. Supported by the St. Louis Fed's long-time research director Homer Jones and his staff economists, Francis had vigorously advocated monetarist policy prescriptions. Although not an economist himself, Roos adopted the monetarist viewpoint of his predecessor and staff in his public remarks and statements at FOMC meetings. $\underline{5}$ At first, Roos counseled patience with the new regime even when economic activity faltered. Over time, however, he and his staff grew increasingly critical as the Fed was either unable or unwilling to hit consistently its announced targets for money growth. Whereas Roos's speeches and remarks at FOMC meetings reflected an unwavering monetarist position, Volcker was a pragmatist who was unwilling to pursue strict monetary targeting when the relationship between money growth and nominal spending appeared to break down and the economy faltered. Drawing from the public remarks and statements at FOMC meetings of Volcker and Roos and articles in the Federal Reserve Bank of St. Louis Review, we document the growing divisions between Volcker's policies and the strict monetarist position of the St. Louis Fed, from the adoption of the new operating procedures in October 1979 to their abandonment in October 1982. 
This article is primarily retrospective. One of our motivations for writing the article is to honor one of the major players in a key episode of the Fed's history. Volcker was a forceful leader who acted on his conviction that a regime change was necessary to bring inflation under control. Many of the obituaries and commentary after his death approvingly cited Volker's commitment to restoring price stability and the Fed's credibility. - Volcker's policies were controversial at the time, however, and arguably contributed to a severe "double-dip" recession in 1980-81. However, in hindsight at least, they have been widely hailed as appropriate and necessary to win the fight against inflation. ${ }^{-}$Besides offering a new perspective on this important episode in U.S. monetary history, the article illustrates some of the challenges a central bank can face when it adopts a new policy framework and how the Volcker Fed navigated those challenges. We conclude by considering the lasting influence of the "monetarist experiment" on Federal Reserve monetary policy and in particular how Volcker adapted the Fed's operating framework in a way that preserved the fundamental focus of policy on price stability

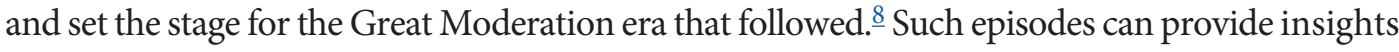
for policymakers contemplating significant changes in their policy frameworks, such as the FOMC framework review announced in late 2018.9

The next section provides background on the 1979-82 regime and the motivation for adopting new operating procedures. Section 3 briefly discusses some key aspects of the procedures. Sections 4 and 5 draw on Roos's speeches and FOMC remarks and select articles in the Federal Reserve Bank of St. Louis Review, to illustrate how Volcker's policies diverged from the monetarist positions long advocated by the leaders and economists of the St. Louis Fed. Section 6 discusses the legacy and lessons of the Fed's "monetarist experiment" of 1979-82.

\section{THE GREAT INFLATION}

The Fed adopted the new operating procedures in the midst of what is now called the Great Inflation. $\frac{10}{}$ For the first half of the 1960 s, inflation, as measured by the 12 -month percent change in the all-items consumer price index (CPI), was relatively low and stable, averaging less than 2 percent. Beginning in the latter half of the decade, inflation began an inexorable rise. As seen in Figure 1, the 1970-71 and 1973-75 recessions temporarily reduced inflation. However, the disinflation did not persist, as each successive recession saw a higher rate of inflation than the previous recession's peak. By the time of the 1980 recession, CPI had reached nearly 15 percent, a high not seen in more than 30 years. $\underline{11}$

Much of the academic literature and the reflections of many current and former Federal Reserve policymakers and economists point to the failure of monetary policy to restrain inflation. The Federal Reserve had three Chairmen in the Great Inflation era before VolckerWilliam McChesney Martin Jr., Arthur Burns, and G. William Miller. Burns most notably blamed inflation on various nonmonetary forces, though he was not the only Fed policymaker to minimize the role of monetary policy. Fed Governor Sherman Maisel, for example, expressed a widely held view among Fed officials that rising inflation in the 1960s and early 1970s was caused by "government deficits;... speculative investment in plant, equipment, and labor by business corporations;... use of economic power to raise wages and profits;... 


\section{Figure 1}

\section{The CPI Inflation Rate, 1960 to 1984}

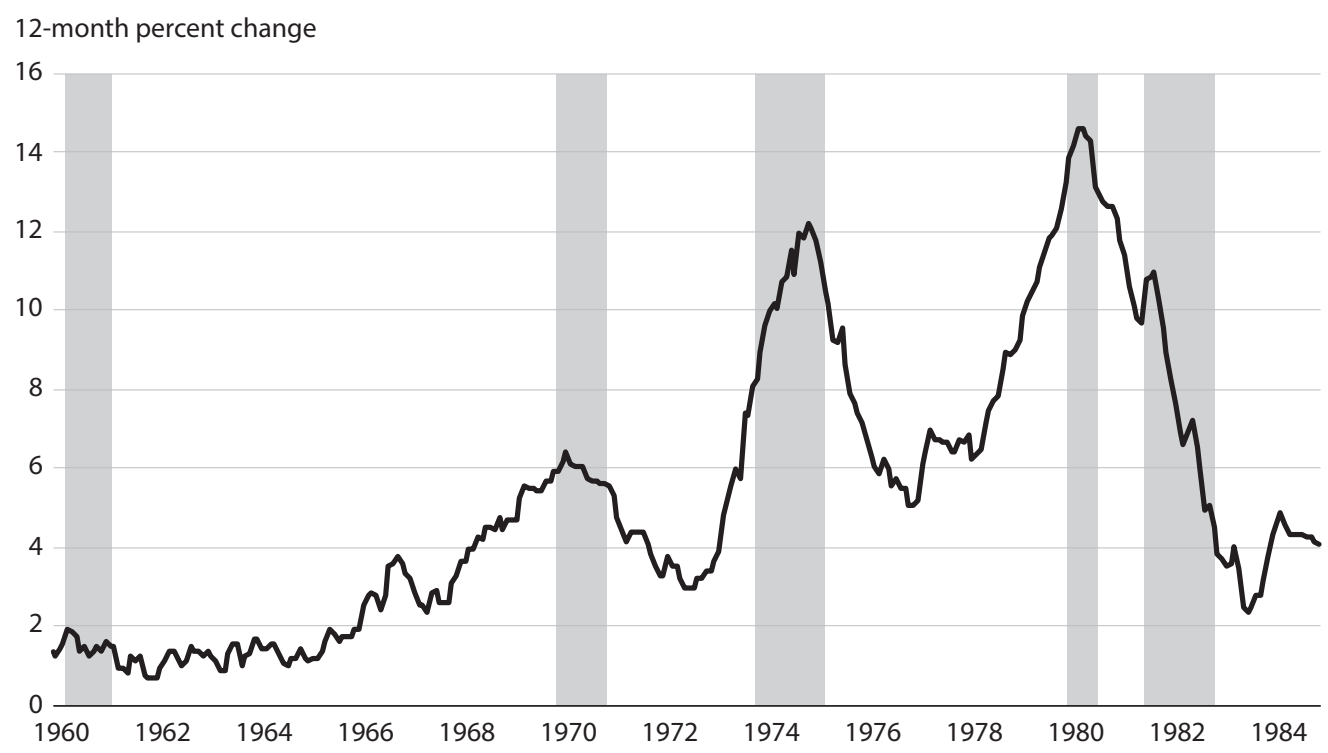

NOTE: Gray bars indicate recessions as determined by the National Bureau of Economic Research.

SOURCE: Bureau of Labor Statistics and Haver Analytics.

But most significant were the government budget deficits." 12 Volcker would later comment that he had been "uncomfortable" with Burns's monetary policy during Volcker's tenure at the Treasury Department in the early 1970s. $\frac{13}{}$ However, like Burns and others, Volcker attributed inflation to multiple causes, including the two oil price shocks of the 1970s, though Volcker acknowledged that monetary policy had "contributed" to the Great Inflation. $\underline{14}$ Other than at the Federal Reserve Bank of St. Louis, there was little acceptance within the Federal Reserve System of the view that inflation was caused by excessive growth of the money supply or that tighter monetary policy was capable of reducing inflation, at least not without causing a severe and unacceptable recession. $\frac{15}{\underline{ }}$

St. Louis Fed president Lawrence Roos expressed the monetarist view of inflation often in speeches and statements at FOMC meetings, including this particularly succinct example:

The cause of inflation is a consistent growth of the money supply that exceeds the growth of economic output. It is not excessive wage demands, large government deficits or the adverse balance of trade that causes inflation. These are the results of inflation. It is the

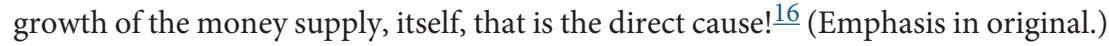

The views that Roos expressed reflected the monetarist position that irresponsible monetary policy had caused the Great Inflation. For example, in 1979, future St. Louis Fed president and noted monetarist William Poole wrote that despite Burn's vociferous warnings about the dangers of an inflationary monetary policy, "It pains me to have to say it, but under Arthur Burns Federal Reserve policy permitted money growth zigzags to accumulate to produce one 
of the most inflationary policies over an eight-year period of any eight-year period since the establishment of the Federal Reserve System." 17

Volcker came into office with a clear determination to restore price stability. Indeed, he told President Carter as much prior to his nomination. $\underline{18}$ Volcker advocated a "practical monetarism," however, rather than the strict constant money growth rule advocated by Friedman. 19 In 1979, that meant publicly committing the Fed to controlling the growth of monetary aggregates, which Volcker saw as necessary to establishing the Fed's anti-inflation credibility and the only way to persuade the FOMC to tighten policy sufficiently to break the inflation psychology that had become cemented in financial markets. $\underline{20}$

\section{THE NEW OPERATING PROCEDURES}

Much has been written about the Fed's regime change in October 1979. We do not provide a detailed explanation of the mechanics of the new framework here, but instead focus on the FOMC's motivation for adopting new procedures and how monetary policy subsequently evolved. For Volcker, restoring the Fed's credibility with markets was a key motivation for switching to a monetary targeting framework. When asked later why the Fed had so much difficulty establishing its credibility in the fight against inflation, Volcker responded, "Because you had gone through a decade of rising inflation and a chorus of criticism. It was a constant feeling that we were behind the curve in dealing with inflation." $\underline{11}$

Volcker was especially sensitive to the market's interpretation of three dissenting votes against a discount rate increase in September 1979, worrying that they would signal a disinclination to tighten policy going forward. Thus, Volcker argued that a dramatic move was required to change inflation expectations: "So I thought, 'We've run out of steam on this particular approach. Let's think of something that's really going to impress the market."'2ㅡㄹ

\section{Summary of the New Procedures}

The new procedures were designed to improve the Fed's control over the growth rate of monetary aggregates. At a basic level, they reflected a change in the relative weights that the Committee placed on money growth versus the federal funds rate. The FOMC had monitored the growth of monetary aggregates since the early 1970s, and in response to a Congressional resolution had been setting explicit target ranges for money stock growth since 1975. $\frac{23}{\text { Lang }}$ (1980, pp. 9-10) summarizes the FOMC's procedures before the October 1979 change as follows:

\footnotetext{
The FOMC at each meeting set an intermeeting range for the federal funds rate, along with tolerance ranges for M1 and M2 growth over the following two months. Within the federal funds rate range, the Committee specified an initial level of the funds rate that was thought to be consistent with the short-run ranges set for M1 and M2. The two-month ranges for M1 and M2, in turn, were intended to provide an indicator to determine when changes to the federal funds rate should be made (subject to its own range). These short-run ranges were specified over moving two-month periods.
} 
The federal funds rate was the FOMC's operating target, and the Committee instructed the Manager of the System Open Market Account to use open market operations to adjust the funds rate within a fairly narrow range, typically 50 to 75 basis points. If conflicts between the federal funds rate and money growth targets arose, the FOMC usually gave precedence to the funds rate target (Lindsey, 1986).

In proposing the new framework to the FOMC, Volcker explained that the procedure "involves managing Desk operations from week to week essentially with a greater effort to bring about a reserve path that will in turn achieve a money supply target...recognizing that it would require a wider range for the federal funds rate." $\underline{24}$ The FOMC expanded its tolerance range for the federal funds rate, initially to 400 basis points, and no longer specified a target level for the federal funds rate as the short-run operating objective. For example, the Committee's October 6, 1979, policy directive stated that the FOMC "seeks to restrain expansion of reserve aggregates to a pace consistent with deceleration in growth of M1, M2, and M3 in the fourth quarter of 1979 to rates that would hold growth of these monetary aggregates over the whole period from the fourth quarter of 1978 to the fourth quarter of 1979 within the Committee's longer-run ranges, provided that in the period before the next regular meeting the weekly average federal funds rate remains within a range of $11 \frac{1}{2}$ to $15 \frac{1}{2}$ percent." $2 \underline{5}$

Whereas the old procedure involved using open-market operations to stabilize the federal funds rate, under the new procedure, the Desk used open market operations to achieve a path for nonborrowed reserves that staff projected as appropriate for achieving the Committee's growth objectives for the M1 and M2 monetary aggregates, so long as the federal funds rate remained within its now much wider tolerance range. According to Lang, "In effect, the new procedures allow the Manager of the System Open Market Account to stabilize growth of nonborrowed reserves within narrower limits. The old procedure, in contrast, forced the Manager to keep the federal funds rate within narrow limits, which resulted in wider fluctuations in the growth of non-borrowed reserves." 26

Although typically referred to as a change in operating procedure, the Fed's new policy framework was more than a simple technical change. Meltzer writes that "The change in operating procedures intended to signal the change in the System's commitment to put greatest weight on inflation and expectations of inflation... The objective was much more important and durable than the change in procedures." 27 The new regime represented a fundamental departure from previous policy. For the first time, the Fed accepted two key monetarist principles: (i) that inflation is a monetary phenomenon and thus the responsibility of the central bank and (ii) that reducing inflation requires slowing the growth of the money stock. These two principles underpinned Milton Friedman's famous assertion that "inflation is always and everywhere a monetary phenomenon" and his advocacy of a constant money growth rate rule for monetary policy. $\underline{28}$

\section{SUPPORT FOR VOLCKER AND THE NEW OPERATING PROCEDURES}

Volcker was firmly committed to price stability. He rejected the idea of a tradeoff between the Fed's inflation and employment goals: " $[\mathrm{M}]$ y basic philosophy is over time we have no 
choice but to deal with the inflationary situation because over time inflation and the unemployment rate go together... The growth situation and the employment situation will be better in an atmosphere of monetary stability." $\underline{29}$ In rejecting an exploitable tradeoff between inflation and unemployment, Volcker was aligned with the St. Louis Fed's traditional monetarist view. That view was developed under Homer Jones, the Bank's research director in the 1960s and early 1970s, and advocated by the Bank's presidents, notably Roos and his immediate predecessor, Darryl Francis (Hafer and Wheelock, 2003). Like the monetarists, Volcker believed that reducing inflation required controlling the growth of the money stock: "To my mind, monetary aggregate targets are a useful—even a necessary-gauge of appropriate monetary policy action in bringing inflation under control." $\underline{30}$ And he testified that controlling growth of monetary aggregates was "indispensable... if we're going to have price stability...If the growth of money is excessive over a period of time, we're going to have inflation." $\underline{31}$

The president and staff of the Federal Reserve Bank of St. Louis strongly supported the FOMC's new operating framework. $\frac{32}{}$ During the October 6, 1979, FOMC meeting, Volcker presented two options to the Committee for the effort to reduce inflation and inflation expectations: (i) a "traditional" approach centered on increases in the discount rate and the federal funds rate and (ii) "a change in the emphasis of our operations." 33 Volcker elaborated on the second option later in the discussion: "This is a time when it may be particularly important to our credibility and to the economy and to psychology and everything else that we provide ourselves with greater assurance that we will get a handle on the money supply." $\underline{34}$

Not surprisingly, the proposed change in operating procedures was music to Roos's ears: "Well, Mr. Chairman, I assume that my credibility with you and my colleagues would be severely jeopardized if I came out flatly in opposition to this proposal! (Laughter) I also was told by my father to keep my mouth shut when things are going well. So all I'll say is briefly: God bless you for doing this! (Laughter)." $\underline{35}$ The following Monday, Columbus Day, the Wall Street Journal published a story quoting several monetarists, including an ecstatic Roos: "Except for the unfortunate coincidence of the holiday, champagne and beer would be flowing in the aisles here." $\underline{6}$ A few days after the Committee's announcement of new procedures, Roos publicly praised the new approach using more measured language:

The announcement by Chairman Volcker on Saturday, October 7, that the Federal Reserve is changing its procedures of monetary policy-making to place more emphasis on controlling growth of the reserve aggregates while permitting interest rates to fluctuate freely, represents a giant step in correcting past mistakes. There is no doubt in my mind that if this new approach is effectively implemented in the upcoming months and years, we can achieve control over the growth of money and, consequently, control over the "basis" rate of inflation. Similarly, we can avoid the adverse real sector impacts that have resulted from unintended drastic short-run fluctuations in the growth of money around its longer-run trend rate of growth...I am enthusiastic and encouraged about the change in the policy-making process that has occurred. $\underline{37}$

In a speech to the American Bankers Association on October 9, 1979, Volcker outlined the policies adopted and said that "this is a time for testing - a testing not only of our capacity collectively to reach coherent and intelligent policies, but to stick with them." $\underline{38}$ He warned the bankers, and implicitly the public, that the road ahead would be difficult: 
[T] hose measures were not designed to make your life as bankers easier. Their purpose is rather to deal forcefully and responsibly with the economic and financial situation as we see it: strong inflationary pressures; concern, exaggerated concern in my judgment, that excessive growth in money and credit might be permitted by the Federal Reserve, fueling still more inflation; and an emerging speculative atmosphere and unsettled markets that could only complicate the job of restoring and maintaining orderly economic growth at home and stability in the dollar abroad. $\underline{\underline{39}}$

Roos and the St. Louis Fed staff remained supportive of Volcker and his policies, at least for a time. In early 1980, Roos publicly praised the FOMC's announced targets for growth of the monetary aggregates: "The policy goals for money growth for the year 1980, as announced today by Chairman Volcker, are clearly a step in the right direction for reducing inflation in the 1980s." Roos also denied that the policy would cause a recession: "While a recession might occur in 1980 as a result of certain non-monetary induced factors such as excessive increases in energy prices, monetary policy, if kept within its announced targets, will not contribute to such downward pressures." And he was confident in Volcker's resolve: "I believe we will stick to our new game plan. I base this belief on my personal knowledge of Paul Volcker as being a courageous and determined Chairman who has succeeded in gaining unanimous support of the members of the Federal Open Market Committee for the new program." Further, "If the Federal Reserve is to maintain its credibility, it must adhere to its new direction of policy." $\underline{40}$

\section{A GROWING DIVIDE}

Behind the scenes, Roos worried that the FOMC was not doing enough to hit its money stock growth targets. Referring to frequent deviations of actual from target money growth, Roos argued that "[T] hese overshoots and shortfalls are not totally beyond our control... We do have the ability at least to influence the growth of money in a very significant manner. I think not only is the credibility of our October 6 program at stake, but the very credibility of the Open Market Committee is at stake in terms of whether or not we perform what we've said we were going to accomplish." $\underline{11}$

Volcker countered that given all of the risks to the economy, "what impresses me is that the greatest risk in the world is not whether we miss our targets or not. I don't want to miss our targets, but we have to put that in perspective of what is going on in the rest of the world. I don't think we can avoid some judgment about what we should do to minimize those risks. We can't escape them. But I don't consider it a full answer to say we set down a target some time ago and we've got to hit the midpoint of that target, as much as I would like to do that in general." $\underline{2}$

Volcker reiterated this view at another meeting:

I think we have to recognize, first of all, that there is a certain artificiality in talking about these targets, however much the market is preoccupied with them and however much we are preoccupied with them. We talk about our credibility and that's important. But credibility over time has to bear some relation to what is possible and what is desirable. And these targets were not exactly written in heaven. They were written by fallible people. And there are a lot of uncertainties in the economy and a lot of changes occurring in it. I'd love to meet these targets, but it is not absolutely the be all and end all of existence. $\underline{43}$ 


\section{Table 1}

\section{Longer-Run Growth Rate Ranges Adopted for the Monetary and Credit Aggregates}

\begin{tabular}{lccccc} 
& \multicolumn{2}{c}{ Period } & & \multicolumn{2}{c}{ M2 } \\
\cline { 2 - 3 } \cline { 5 - 6 } & Range adopted & Actual & & Range adopted & Actual \\
\hline March 1975-March 1976 & $5.0-7.5$ & 5.3 & & $8.5-10.5$ & 9.7 \\
\hline 1975:Q4-1976:Q4 & $4.5-7.5$ & 5.8 & & $7.5-10.5$ & 10.9 \\
\hline 1976:Q4-1977:Q4 & $4.5-6.5$ & 7.9 & & $7.0-10.0$ & 9.8 \\
\hline 1977:Q4-1978:Q4 & $4.0-6.5$ & 7.2 & & $6.5-9.0$ & 8.7 \\
\hline 1978:Q4-1979:Q4 & $3.0-6.0$ & 5.5 & & $5.0-8.0$ & 8.3 \\
\hline 1979:Q4-1980:Q4 & $4.0-6.5$ & $7.3^{\mathrm{c}, \mathrm{d}}$ & & $6.0-9.0$ & 9.6 \\
\hline 1980:Q4-1981:Q4 & $3.5-6.0$ & $2.3^{\mathrm{c}, \mathrm{e}}$ & & $6.0-9.0$ & 9.5 \\
\hline 1981:Q4-1982:Q4 & $2.5-5.5$ & $8.5^{\mathrm{c}}$ & & $6.0-9.0$ & 9.2 \\
\hline 1982:Q4-1983:Q4 & $5.0-9.0^{\mathrm{f}}$ & 7.2 & & $7.0-10.0$ & 8.3 \\
\hline 1983:Q4-1984:Q4 & $4.0-8.0$ & $4.0-7.0$ & & $6.0-9.0$ & \\
\hline 1984:Q4-1985:Q4 & & & & $6.0-8.5$ & \\
\hline
\end{tabular}

NOTE: a At the February 1979 meeting, the FOMC adopted a range for M1 for 1978:Q4 to 1979:Q4 of 1.5 to 4.5 percent. This range anticipated that shifting to ATS and NOW accounts in New York State would slow M1 growth by 3 percentage points. At the October meeting, it was noted that such shifts would reduce M1 growth by no more than 1.5 percentage points. Thus, the longer-run range for M1 was modified to 3 to 6 percent.

${ }^{b}$ Adopted at the February 1980 meeting, when the monetary aggregates on which these targets were based were redefined and new target ranges adopted.

C The figures shown reflect target and actual growth of M1-B in 1980 and of shift-adjusted M1-B in 1981. M1-B was relabeled M1 in January 1982. The targeted growth for M1-A was 3.5 to 6 percent in 1980 (actual growth was 5 percent); in 1981, targeted growth for shift-adjusted M1-A was 3 to 5.5 percent (actual growth was 1.3 percent). $d$ When these ranges were set, shifts into other checkable deposits in 1980 were expected to have only a limited effect on growth of M1-A and M1-B. As the year progressed, however, banks offered other checkable deposits more actively and more funds than expected were directed to these accounts. Such shifts are estimated to have decreased M1-A growth and increased M1-B growth each by at least 0.5 percentage points more than had been anticipated.

e Adjusted for the effects of shifts out of demand deposits and savings deposits into other checkable deposits. At the February FOMC meeting, the target ranges for observed M1-A and M1-B in 1981 on an unadjusted basis, expected to be consistent with the adjusted ranges, were -4.5 to -2 percent and 6 to 8.5 percent, respectively. Actual M1-B growth (not shift adjusted) was 5.0 percent.

f Base period, adopted at the July 1983 FOMC meeting, is 1983:Q2. At the February 1983 meeting, the FOMC had adopted a target range for 1982:Q4 to 1983:Q4 for M1 of 4 to 8 percent.

9 Base period is the February-March 1983 average.

h Adopted at the February 1984 meeting.

i Tentatively adopted at the July 1984 meeting. SOURCE: Lindsey (1986).

Whereas Volcker equivocated about the need to hit the FOMC's monetary targets, Roos remained adamant about the importance of staying the course: "Mr. Chairman, I think it's more than the process. There is a very fundamental issue at this stage. The way this meeting is going and the way opinion is apparently evolving, we are getting right back to setting interest rate ranges and the stabilization of interest rates, and I could not go along with that. I think we're turning the corner, all for the worse, to right back where we were." $\underline{4}$ 
Figure 2

The Discount Rate and the Federal Funds Rate, 1979 to 1983

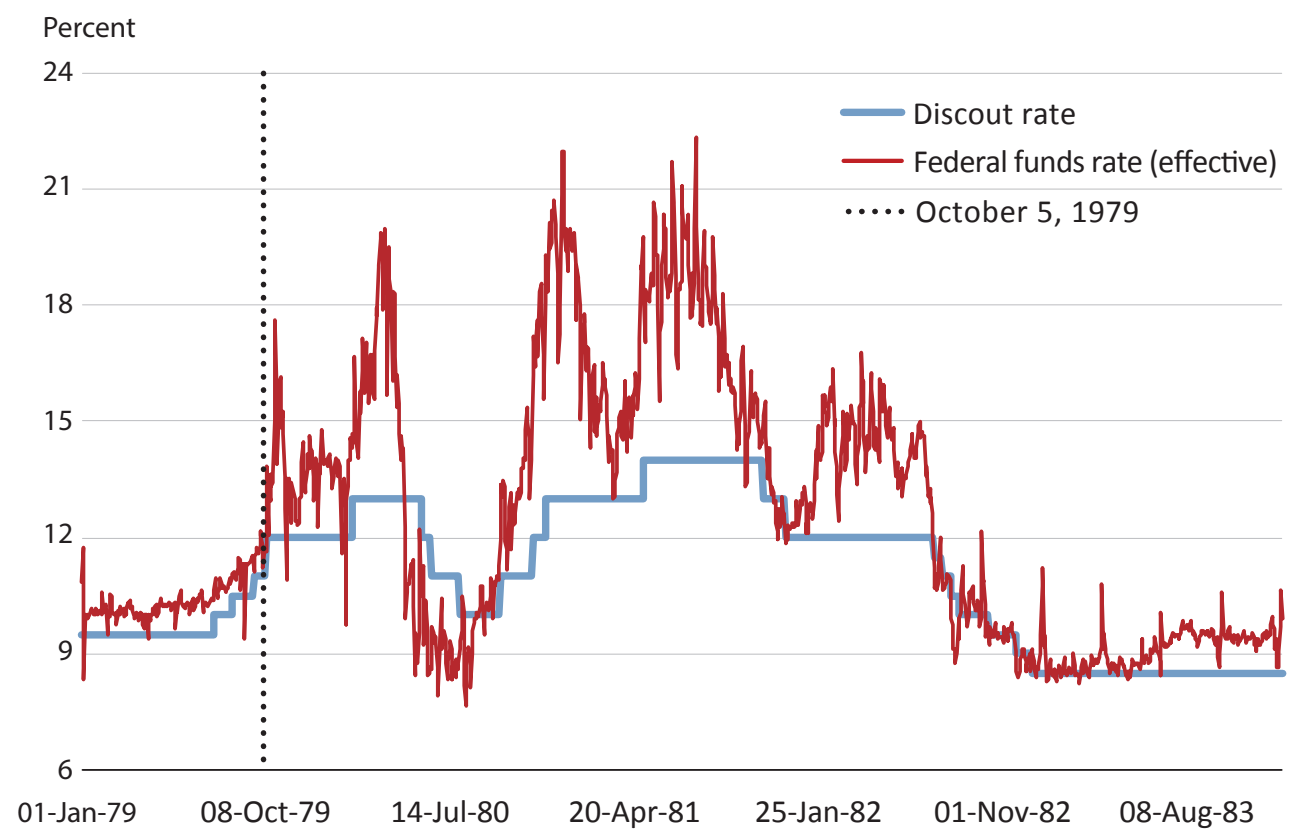

SOURCE: Federal Reserve System and Haver Analytics.

The FOMC's record at achieving its targets for money growth was spotty at best, and a continual source of frustration for Roos and disagreement with Volcker (as well as with some other FOMC participants and Board of Governors staff). Table 1 reports the annual monetary growth rate ranges for the M1 and M2 monetary aggregates. M1 growth exceeded the top end of its target range in three of four years from 1977 to 1980. M1 growth then slowed sharply in 1981 but accelerated again in 1982. M2 growth followed a similar pattern, exceeding the top end of its annual ranges in five of the nine time periods from March 1975 to the end of 1983.

Publicly, Roos remained aligned with Volcker as external critics began to find fault with the FOMC's new policy. The federal funds rate, which had traded close to 12 percent before the Fed's October 6, 1979, announcement, jumped to 16 percent in late October before settling in the range of 12-15 percent over the remainder of the year (Figure 2). The funds rate rose again sharply in 1980, peaking at nearly 20 percent in early April, then fell as the economy entered a recession.

Roos defended the Fed and Volcker over high interest rates, arguing that monetary policy had "very little to do" with the increase in interest rates: "The Fed can cause a temporary increase in interest rates only by dramatically restricting the growth of bank reserves, and this has not been the case in recent months." He went on to argue for staying the course in the fight against inflation: "The surest way to destroy a democracy is to tolerate runaway inflation." $\underline{4}$ 


\section{Figure 3}

\section{Growth Rate of the M1 Money Stock, 1972 to 1983}

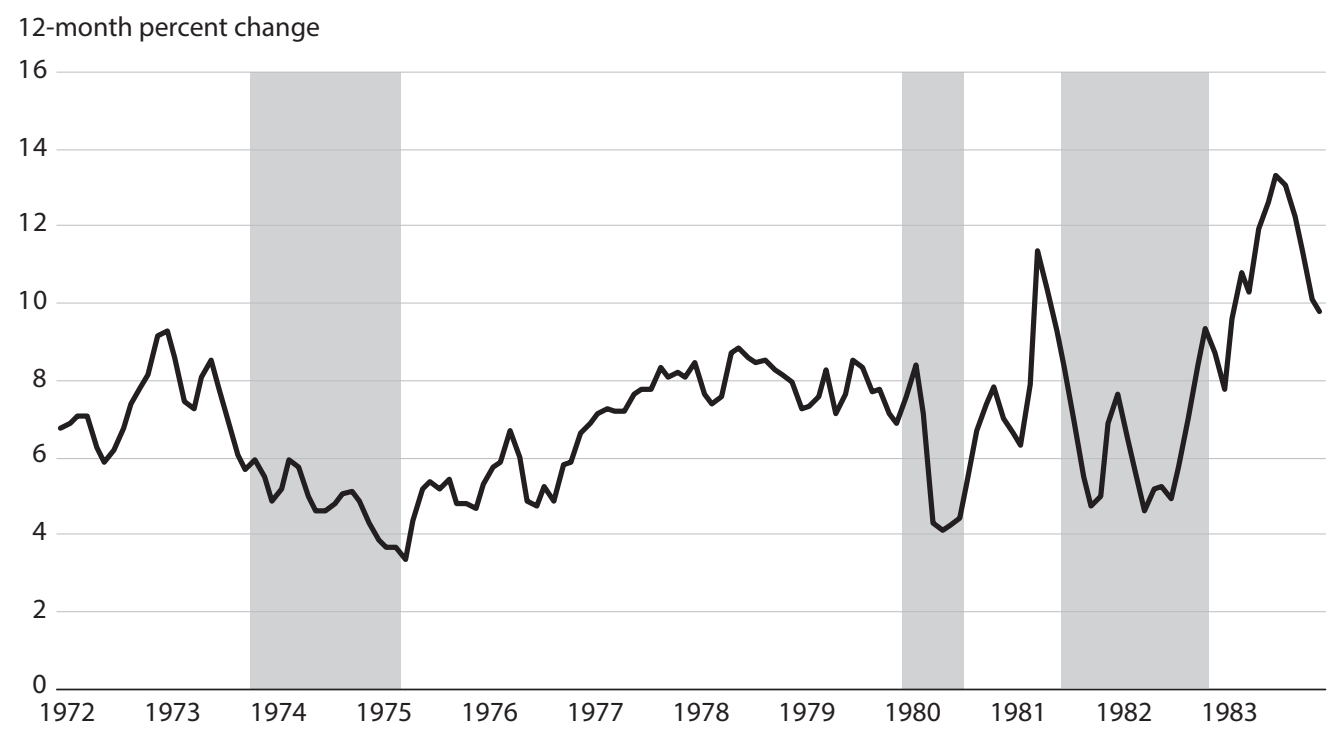

NOTE: Gray bars indicate recessions as determined by the National Bureau of Economic Research.

SOURCE: Federal Reserve System and Haver Analytics.

In a subsequent speech, Roos explained the impact of inflation expectations on interest rates: "As more people become convinced that the rate of growth of money is indeed being controlled and will continue to be reduced, inflationary expectations will recede and interest rates will continue to decline." $\underline{46}$

The Fed was widely blamed for the 1980 recession, which lasted from January to July of that year, and for a second, much deeper recession from July 1981 to November 1982. 47 Subsequent research generally agrees that tighter monetary policy contributed to the recessions but that oil price shocks likely also played a role. $\underline{48}$ The first shock followed the Iranian revolution in 1978, and the second was triggered by Iraq's invasion of Iran in September 1980 (Hamilton, 2011). Oil production fell sharply in both instances, causing the spot price of West Texas Intermediate crude oil to rise from about $\$ 15$ per barrel in December 1978 to an average of $\$ 39.50$ per barrel from April 1980 to July $1980 . \underline{49}$

Credit controls also contributed to the 1980 recession. The Fed imposed credit controls in March 1980 at the request of the Carter Administration. Volcker later argued that the 1980 recession was "kind of artificial" and largely caused by the credit controls, and that the episode "was a good lesson in unexpected results of government intervention." $\underline{50}$ Further, "[W]e put [controls] on one day, with a big White House announcement by the President, and the economy collapses the next day...Consumption just collapsed." 11 Money supply growth also weakened, partly a result of the credit controls, with $\mathrm{M} 1$ growth for the year of just 2.3 percent, well below the FOMC's target range of 3.5 percent to 6 percent (see Table 1). 
Credit controls were discontinued on July 3 , and both the economy and money stock growth soon began to recover. As seen in Figure 3, after slowing from 8.4 percent in February 1980 to 4.1 percent in May 1980, M1 began to grow strongly, reaching an annual growth rate

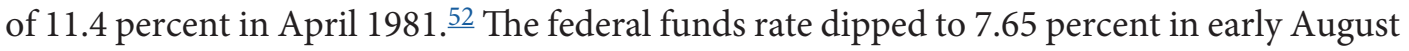
and then started to increase. Roos pointed out that rising interest rates did not imply that monetary policy was tightening: "In the period from June to December 1980, the basic money supply grew at $14 \%$, well above the Fed's announced target ranges and far in excess of the inflation-generating rates of growth that have occurred over the past several years. The present high interest rates are not caused by 'tight' credit policies, but rather by overly expansive monetary policy." Roos remained steadfast in his view that the Fed should stay committed to controlling the growth of monetary aggregates: "During the year [1980] the money supply both overshot and undershot our announced targets to such an extent that some observers are questioning both the ability and the determination of the Fed to achieve its new objectives. I do not believe that the experience of one year is proof of the success or failure of the Fed's new operating procedures... So I would hope that the Federal Reserve reaffirms its commitment to its program of monetary control as announced in October 1979, and revises, if necessary, its operating techniques in order to enable it better to hit its targets." $\underline{53}$

In a speech to the American Farm Bureau Federation in early 1981, Volcker acknowledged that "growth of the various money and credit measures during 1980 was close to, and in some instances slightly above, the upper end of the ranges set at the start of the year." However, he stressed that "inflation is our number one problem." Further, "inflation is the result of longterm monetary problems related to...the nation's supply of money and credit to finance federal deficits." $\underline{54} \mathrm{He}$ went on to say that while he sympathized with the plight of those facing higher interest rates, the Fed would not be deterred from its commitment to fighting inflation:

Cyclical interest rate movements are, of course, not a new experience for farmers generally. But I well understand that many of you find the current interest rate experience shocking and alarming. I have been made very aware of both the mounting strains of current interest rate levels and your fears for your future financial condition if the current levels of credit costs are permanent rather than a cyclical or temporary phenomenon. I sympathize with those concerns. But let me say frankly, I see no escape from those problems by easing restraint on money and credit growth-by pumping up the money supply. Unfortunately, the historical record seems clear that it is inflation and not real growth that would increase as a result. Sooner or later-and it is all too likely to be soonerinterest rates would rise again, as inflation became even more embedded in our society. $\underline{55}$

Roos, of course, agreed with the sentiments about inflation that Volcker expressed to the Farm Bureau Federation. However, he publicly criticized the Fed for allowing "excessive gyrations [in money growth], and the associated erratic behavior of interest rates, [which] led to increased uncertainty as to the intended course of monetary policy and resulted in severe instability in financial markets. Thus, from the standpoint both of reducing inflation as well as achieving financial stability, the first year of the Fed's new program was disappointing." According to Roos, “The problem was one of procedure, not purpose." And, “The Fed's reluctance to change its operating techniques to a sufficient extent was, in my opinion, the primary cause of the poor results of 1980." Roos went on to argue that the Fed should use the growth of 
either total reserves or the monetary base as its operating target. He contended that targeting nonborrowed reserves did not work well because the Fed's Open Market Desk would frequently alter the path of nonborrowed reserves in response to unforeseen changes in borrowed reserves. The problem, he argued, is that "Effective monetary control requires that reserves serve as a constraint on future money growth, rather than an accommodation of lending actions already taken by banks." Further, he argued, "The Federal Reserve should eliminate all constraints on the federal funds rate. This change is, perhaps, the most crucial of all." $\underline{56}$

Roos's public criticism of the FOMC's approach alarmed Volcker, who saw the drumbeat of criticism from St. Louis as "undermining the Fed's position." In response, Volcker dispatched Vice Chairman Frederick Shultz to meet with the St. Louis Fed's Board of Directors in May 1981. According to Greider (1987, p. 390), the purpose was to upbraid Roos-"to muzzle their feisty president." The effort seems to have been largely unsuccessful, as Roos and his staff continued to speak and write critically about the Fed's monetary policy.

The economic expansion that began in mid-1980 continued well into 1981. Roos was generally satisfied with policy in the first half of 1981 and urged resolve in the fight against inflation: "[A]lthough money growth has been somewhat slower than its targeted path for the past four months and interest rates remain stubbornly high, we are now closer to our announced annual money growth paths than we were at this time last year. Furthermore, I am convinced that the Federal Reserve is steadfast in its determination not to exceed its 1981 targets." Roos was also pleased that the FOMC seemed to be paying less attention to interest rates: "Since October 1979, and following the Fed's 'learning experience' in 1980, monetary policy has focused primarily on controlling the monetary aggregates rather than stabilizing interest rates. We no longer try to constrain short-term fluctuation in interest rates." 57

\section{Dissatisfaction with $M 1$}

The growth of monetary aggregates remained erratic, however, and the growth rates of different aggregates diverged. The Fed introduced a new aggregate, "shift-adjusted M1B," in 1981 to account for the nation-wide introduction of the NOW account (an interest-bearing checkable deposit) in January of that year (Thornton, 1982a). In the St. Louis Fed's annual review of monetary policy over the preceding year, Thornton documented the FOMC's conundrum as the different aggregates diverged: "During most of the year, the Committee allowed shift-adjusted M1B to grow below the bottom of its annual target range when M2 grew within or at the top of its range. In the fourth quarter of the year, M2 was permitted to exceed the top of its annual range when the Committee increased the priority for a faster growth of the narrower aggregate in response to declining economic activity." $\underline{58}$

The divergent growth rates of the different monetary aggregates led to calls for abandoning one or more of the aggregates altogether. Many argued for dropping the narrower M1 aggregates because they seemed especially sensitive to financial innovations and regulatory changes. By early 1980, Volcker was already suggesting a preference for focusing on the broader aggregates. For example, at the May 1980 FOMC meeting, he noted the following: "The thing that preoccupies me a little here-and I recognize that this is also the staff's best professional judgment-is that the M2 and M3 figures are not as bad, in the sense of a decline, as are the M1 figures. We've been putting an awful lot of weight on M1 because we get it weekly and it's a 
more immediate operating variable. But we used to do an awful lot of talking about how important M2 and M3 were; and a lot of people thought they were more significant (than M1)." 59

Bolstered by research produced by his staff economists, Roos remained loyal to M1, arguing that it is both more controllable and more closely correlated with growth in nominal spending:

[C]onsistency is terribly important...I think you [Volcker] should tell Congress that we have fallen below the lower limits of our announced ranges for the narrow aggregates and that we are going to do what is necessary to get back within the ranges...We are going to get back into these ranges because we do not want to exacerbate the recession we are in. We don't want to make it worse by continuing (to foster) growth of the narrow aggregates below the ranges...Incidentally, our people did a study of M2 and they feel that M2 is not an accurate predictor of GNP [gross national product], so I'd resist moving to place greater emphasis on our M2 targets. $\underline{60}$

Roos and Volcker continued their debate about monetary aggregates over the ensuing two years. At the March 29-30, 1982, FOMC meeting, for example, Roos again expressed concern about volatile M1 growth, arguing that "if there is an April bulge [in M1 growth], it should be brought down almost as quickly as possible in order to permit money to grow gradually over the last part of the year." Volcker acknowledged Roos's concern but reaffirmed his desire to focus on M2: "Given all the problems we have, I think it may make more sense in the short run-or even in the long-run period given the doubts about what M1 means in some cases-in effect to watch pretty closely what is happening to M2." 11

Roos also advocated for focusing on narrow monetary aggregates in his public remarks. Noting that recent fluctuations in nominal spending followed changes in M1 growth, Roos argued that "recent events have reaffirmed that M1, as currently defined, is a reliable measure of the thrust of monetary policy actions on the economy." Further, he argued that "The problem was not that the prescribed money targets have been erratic or inappropriate; rather, the problem was that money growth was sometimes inconsistent with the announced targets." However, in his last speech as St. Louis Fed president, Roos acknowledged that temporarily deemphasizing M1 was understandable: "Actually what is being done is perfectly understandable. It was induced by possible temporary distortions in the measurement of M1 and possible temporary shifts in the relationship of M1 to economic activity." Nonetheless, he argued that M1 should ordinarily be the Fed's preferred aggregate, though "there will be times when it will be necessary to redefine the M1 measure to adjust for innovations.” $\underline{62}$

\section{Views on Public Support for Policy}

Aside from debating about which monetary aggregate deserved the Committee's focus, Roos and Volcker also disagreed about the public's level of support for bringing inflation under control. At an FOMC meeting in December 1980, Roos stated: “Mr. Chairman, I'm going to address my brief remarks to the year 1981 in a broader context than usual. And I'm going to base my analysis on three fundamental factors that seem clear to me. One is that there has been an unusually strong indication that the public as a whole places inflation at the top of its list of priorities requiring attack by the government, by agencies such as ours." Volcker replied: 
"If I may just interject a comment, my perspective may be somewhat different. I am impressed by the number of comments I hear along the lines of: 'If this is what dealing with inflation means, I'd rather have inflation." $\underline{63}$

Over the course of the year Roos discussed the importance of public and political support for what the Committee was trying to accomplish. At the July 7, 1981, FOMC meeting he expressed that "For once I feel a lot more satisfied with what is happening than do some of my colleagues here at this table...I think in the last several months our record on monetary policy-our record of holding monetary growth under control—has been quite remarkable." 64 However, Roos's optimism faded later in 1981 as the recession worsened, and during the last few meetings of the year he expressed concern that monetary policy was too tight:

I would preface my remarks by saying that I still consider myself to be as hawkish in my desires to give top priority to dealing with the problem of inflation as one could be. On the other hand, as I recall when we set our annual target ranges this year, they represented a gradual reduction from the previous year and they were intended as an anti-inflationary program...[I]f real output continues to (weaken) significantly, we are going to have in our economy and in our body politic a reaction for strong stimulus next year to get ourselves out of a recessionary situation. And that poses a real threat to our long-term efforts to cope with inflation. $\underline{65}$

Roos was also concerned that the FOMC would revert to its former operating procedures:

I think there's an even more fundamental concern as we look ahead and that is the decision as to whether or not we ought to revert to our former practices. We know that our mission is to try to achieve reasonable price stability and to achieve steady economic growth. As some of you have said, it's not desirable to have (large) variations or ups and downs in interest rates. Well, I would remind you that prior to October of 1979 we spent precious hours discussing whether or not interest rates should be set 1 point or $1 / 2$ point higher or lower. We attempted to conduct monetary policy by targeting on interest rates. $\frac{66}{6}$

Throughout 1982, with the economy in the throes of a deep recession, Roos often reported at FOMC meetings on interactions he had with business and labor leaders, usually indicating that the people he talked to understand the necessity of lowering inflation and the costs it entails:

There's no question that the industries and, of course labor in terms of unemployment, are feeling very severe recessionary pressures. On the other hand-and I was especially interested in this reaction coming from the labor side-these people recognize that this was part of the process of bringing down inflation. They felt that whoever made the monetary policy and fiscal policy decisions of a year or two ago must have known that this downtrend would occur. They see it as a temporary phenomenon...And they were very strong in their support of monetary policy. $\underline{67}$

Roos's contention that the public supported the Fed's efforts to restore price stability undoubtedly reflected both his-and, importantly, Volcker's-frequent public statements that bringing down inflation was crucial to restoring the underlying health of the economy. Volcker made at least 72 public statements-speeches, interviews, and Congressional testimony-between September 5, 1979, and December 14, 1982, or nearly three per month. $\frac{68}{6}$ He said that "[e]very word I uttered was an attempt to educate the public or some member of the Congress. You are always very conscious of that." 69 Key to Volcker's public education 
efforts during this period was his common refrain on the importance of sticking with the new operating procedures. A good example was his interview with ABC News in August 1981:

But I think it is fair to say, I take it as a sign that there is still a lot of doubt, a lot of uncertainty...a lot of concern about economic policy in general, concern focused on whether we are going to be successful in dealing with inflation, whether we are going to stick with it, in the simple term. And my message there would be, yes, we intend to stick with it. $\underline{70}$

\section{The End of the New Operating Procedures}

Throughout 1982, the tension between the commitment to lower inflation and inflation expectations and the natural inclination to support a faltering economy was regularly at the forefront of FOMC deliberations. At the March 29-30 meeting, Volcker noted that the staff was projecting a "pretty good recovery" and that, despite the recession, the Committee should not actively seek lower interest rates but instead preserve progress on inflation. $\frac{71}{}$ However, as the year continued, the combination of slower money growth-and especially interest rate volatility-provided impetus for backing away from targeting monetary aggregates.

At the August 24, 1982, meeting, Volcker stated that he was fed up with the volatility in interest rates. Roos again worried that any de-emphasis of the monetary aggregates would be "read as a signal of a return to stabilizing interest rates." $\underline{2}$ Volcker's frustration was telling, however, and appears to signal the coming end of the monetarist experiment:

I, frankly, cannot live in these circumstances, given what is going on in the money markets, with violent moves in short-term rates in either direction. It would just be so disturbing in terms of expectations, market psychology, and fragility that it's just the wrong policy, period, during this particular period. Again, that is not inconsistent with more moderate movements in either direction depending upon what happens to the aggregates. But I just think we'd end up in sheer confusion-more than confusion; we'd end up with an atmosphere in markets that deteriorates rather than improves things. $\underline{73}$

In public remarks a little less than two months later, Volcker expressed that "there is growing evidence that the inflationary momentum has been broken. Indeed, with appropriate policies, the prospects appear good for continuing moderation in inflation in the months and years ahead." 74 However, he also warned that the days of targeting the monetary aggregatesespecially $\mathrm{M} 1$ - were nearing an end:

We face over the next few months, not just the possibility but the virtual certainty of distortions-distortions growing out of legislation and regulation-in the M1 number that is so widely followed in the markets...In the circumstances, I do not believe that, in actual implementation of monetary policy, we have any alternative but to attach much less than usual weight to movements in M1, over the period immediately ahead. $\underline{75}$

The October 5 meeting was a milestone in that it marked the end of the operating procedures adopted in October 1979. As Figure 4 shows, Roos was an active participant at this meeting, as measured by number of key words spoken. $\underline{76}$ Indeed, his word count at this meeting was surpassed only at the February 1982 meeting. Roos knew the outcome going in, commenting early in the meeting that the plan was to "bury my old friend M1," but he sought to forestall 


\section{Figure 4}

\section{Count of Keywords in FOMC Transcripts by Roos and Volcker}

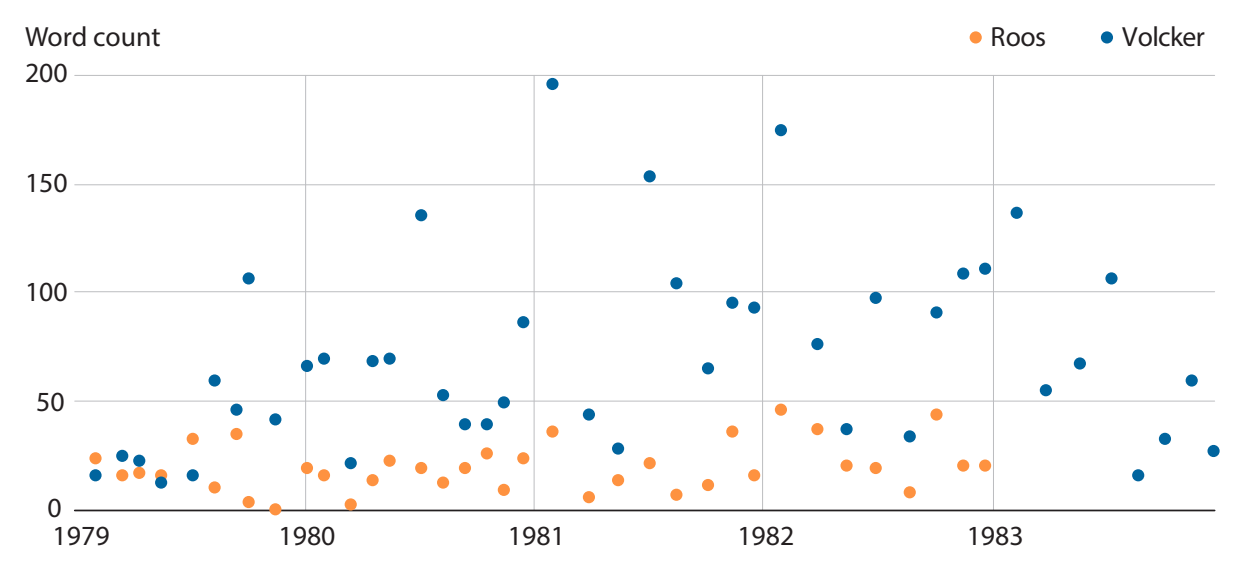

NOTE: Key words include money growth; aggregates; M1; M2; M3; inflation; Friedman; Milton; interest; fed funds; federal funds; and any words that include the prefix "monetar," such as monetary, monetarism, and monetarist.

that outcome by requesting that "some study be done prior to changing our basic approach to policymaking...Couldn't this matter be studied and couldn't we have a summit meeting if necessary... prior to our next meeting of the FOMC to see what the best brains in the System think?" Volcker replied, "Well, yes and no is the answer, I think. Obviously, we can study the matter. I see no prospect that any amount of study is going to tell us what the behavior of M1 is going to be in the short run. It is unknowable, in my opinion, to all the best brains in the world." 77

With his tenure nearing an end, and the monetarist experiment on its death bed, Roos reminded the Committee of all that they had accomplished and warned, again, of the consequences of abandoning the monetary aggregates:

I do take exception to any implication that recent Federal Reserve policy has wrung out the economy of this country or has been detrimental to the international economy. I think what has occurred is more a result of ten or fifteen years of irresponsible monetary policies throughout the world-as well as a well-meant effort on the part of the Federal Open Market Committee as long as I've been on it and until October 1979-to try to do just what we're doing today, and that is to lean against interest rate movements. I think that contributed in a major way to inflation, which really led to this high interest rate pattern that we have. I believe that what we're about to do today will unquestionably be viewed by those who watch what we do as a major change. $\underline{78}$

Roos ended his remarks by praising Volcker's leadership during a difficult period. He added that the FOMC's success in "wringing out the inflationary problem" had improved economic stability and restored the Fed's credibility. However, Roos then warned that it would be a "gross mistake" to remove M1 from the directive because doing so would cause the public to question the FOMC's commitment to price stability. $\underline{.79}$

Volcker acknowledged the passion behind Roos's views, but disagreed about the signal that abandonment of M1 would send to markets and the consequences thereof. He also 
acknowledged the political risk, but argued if the economy weakened again, the Fed would "face legislation" that might limit its ability to conduct an independent monetary policy:

Most people in the financial markets at least, to put it bluntly, think we've overstayed the course now. It gets into this great question of credibility that I suppose we're taking rather personally. At the risk of being misunderstood, following a mechanical operation because we think that's vital to credibility and driving the economy into the ground isn't exactly my version of how to maintain credibility over time. $\underline{\underline{80}}$

The meeting continued with a long discussion over the wording of the policy directive. Roos did not participate in that discussion, and he did not have a vote on the directive. The Committee's directive to the Open Market Desk called for putting "much less than usual weight" on M1 and did not specify growth ranges for that aggregate. $\frac{81}{\text { Although the directive }}$ included targets for M2 and M3 growth, much of the Committee's discussion focused on interest rates and the level of borrowed reserves that the Desk would target in implementing the Committee's directive. $\underline{82}$ Vice Chairman Anthony Solomon reconciled the directive's focus on the broader monetary aggregates with the Committee's interest rate objectives as follows: "(I)f one reads this carefully, we are really not targeting M2. We are targeting basically money market conditions." Volcker described to the Committee that the assumed path for borrowed reserves under the proposed directive "would get a somewhat easier tendency in the federal funds rate... But I haven't any particular target in mind. The implication is that we would keep the borrowing level more or less the same until something happened to throw us off-in economic activity, in financial markets, or in the actual growth of M2 and M3."푸

Three Reserve Bank presidents dissented from the proposed directive: Robert Black (Richmond), William Ford (Atlanta), and Karen Horn (Cleveland). Black and Horn expressed a desire to retain focus on M1, while Ford preferred a tighter policy that was "more firmly directed toward restraining monetary growth." 14 Over their objections, the "monetarist experiment" effectively ended.

The following day, October 6, 1982, Roos gave a speech titled "Does Money Still Matter?" In his remarks, he reaffirmed the traditional St. Louis views about money and monetarism:

[I]t is premature to talk about the death of monetarism... arguments purporting to show that monetarism and monetary targeting have failed are, in fact, groundless...Suggestions that the time has arrived to conduct monetary policy differently are without merit...

$[R]$ recent events have reaffirmed that M1, as currently defined, is a reliable measure of the thrust of monetary policy actions on the economy...

$[\mathrm{M}]$ onetarist propositions did predict fairly precisely the economic consequences of erratically declining money growth since 1979 (emphasis in original)...

[A] gradual reduction in M1 growth... would have reduced inflationary pressures with minimum shocks to real output and employment. The problem was not that the prescribed money targets have been erratic or inappropriate; rather, the problem was that money growth was sometimes inconsistent with the announced targets. $\frac{85}{1}$

Roos said relatively little in the economic and policy discussions at the final two FOMC meetings of his tenure (see Figure 4 and associated note). However, he was not averse to making bold predictions. He made the startling forecast that with faster money growth, lower 
rates and fiscal stimulus, "double-digit inflation" was likely to reemerge unless the Fed hit the brakes:

If you count four or five months into the future, I'll be fishing and you all will still be wrestling with this. But let's assume that by forcing rates down a little you do achieve an improvement in the economy and this stimulus starts causing interest rates to rise next spring as this long-sought recovery is reaching meaningful proportions. Yet money has grown so quickly that the prospect of inflation is heightened. Are you all going to be willing to apply the brakes at the time? If you don't apply the brakes at that time, we're going to be right back into double-digit inflation rates in a few years. $\underline{86}$

Others on the Committee expressed doubt about Roos's scenario, though Volcker did not rule it out "entirely" while again discounting the signal from M1 growth and contending that the bulge in M1 growth was temporary but that M2 growth was likely to slow going forward, as documented in the meeting transcript:

MR. MORRIS. Somehow, Larry [Roos], that scenario doesn't fly with me. I don't think that's the situation we're in.

MR. GRAMLEY. I'd sure be a lot happier about applying the brakes if the car were rolling rapidly down the hill than to roll it backward down the hill.

MR. PARTEE. We'll think of you though, Larry.

CHAIRMAN VOLCKER. I don't discount that (scenario) entirely. It is complicated by the budgetary situation. I don't know that it would happen as soon as this spring, but I think it is possible. As I said before, we will not find this particular monetary growth (pattern) again. I don't know what M1 is going to look like then. I'm not sure we're going to find M2 all that rapid in those circumstances, but we'll have to wait and see. $\frac{87}{8}$

\section{CONCLUDING OBSERVATIONS: THE LEGACY OF 1979-82}

In October 1982, the FOMC abandoned the new operating procedures and largely gave up on controlling the growth of monetary aggregates in favor of returning to a framework more focused on targeting the federal funds rate. The FOMC did not, however, abdicate responsibility for inflation. The policy framework adopted by the FOMC in October 1979 was more than a simple technical change about targeting reserve or monetary aggregates. Rather, it represented a fundamental change in the policy regime. For the first time in its history, the Fed acknowledged the central bank's responsibility for inflation and need to control the money supply to achieve price stability. Although the FOMC abandoned monetary aggregate targeting in late 1982, under the leadership of Paul Volcker and his successors, the Fed remained committed to achieving price stability. Inflation continued to fall, eventually to the 2 percent level that the FOMC, under Chairman Ben Bernanke, determined to be consistent with price stability. $\underline{88}$

Since the Financial Crisis of 2007-09, the FOMC has struggled more with inflation running persistently below its 2 percent target than with keeping inflation down. This difficulty has, in part, led the FOMC to reexamine its policy framework and to consider such options as price level or average inflation targeting, and nominal GDP targeting. .99 Some have questioned 
the credibility of the Fed's commitment to the 2 percent target or whether policymakers view 2 percent as a ceiling rather than a symmetric objective. Seeing the credibility of their inflation objective as critical for achieving price stability, FOMC participants have stressed in speeches and other forums their commitment to the target and in 2019 the Committee revised its statement of long-run goals and monetary policy strategy to make clear that the FOMC would be concerned if inflation was running either above or below 2 percent. The FOMC revised its statement again in August 2020 when it formally adopted average inflation targeting and announced that "following periods when inflation has been running persistently below 2 percent, appropriate monetary policy will likely aim to achieve inflation moderately above 2 percent for some time." 90

The credibility of the FOMC's commitment to price stability was also an important and frequently debated aspect of the Fed's policy regime from 1979 to 1982, and a review of that experience can provide insights for policymakers today. In 1979, Volcker was concerned that the Fed had lost credibility and that an entirely new approach was required to restrain inflation expectations if inflation itself was to be brought under control. The FOMC's strategy of making incremental adjustments to its target for the federal funds rate was not keeping inflation expectations, and therefore actual inflation, from rising. By announcing a new approachostensibly the monetarist approach advocated by academic monetarists as well as the leadership and staff of the Federal Reserve Bank of St. Louis-Volcker sought to break ingrained inflation psychology, establish the Fed's credibility, and thereby bring inflation under control. Unlike Lawrence Roos, however, Volcker was at most a "practical" monetarist, not a purist. He used monetarism as an expedient but was never a firmly committed monetarist. After adopting monetarist-oriented measures in October 1979, Volcker's commitment to targeting monetary aggregates soon waivered when an oil shock, financial deregulation, and credit controls resulted in extreme volatility in both money supply growth and interest rates. He became particularly disenchanted with M1, which was more susceptible to distortions caused by financial deregulation and innovations than M2 and M3. Volcker was willing to allow the growth of all of the monetary aggregates, but especially M1, to deviate from the Committee's targets when doing so seemed appropriate given the state of the economy. He did not, however, give up on the fundamental mission of restoring price stability.

Roos, by contrast, was firmly committed to monetarism throughout his tenure as president of the St. Louis Fed and consistently advocated for setting and hitting targets for the growth of M1. He frequently argued that the Fed's credibility was at stake and that failure to hit the announced targets for money growth would be viewed as backsliding on inflation by returning to the Committee's former operating procedures. For the most part, Roos dismissed the view that the money stock targets were hard, if not impossible, to hit, and he pressed the Committee to adopt procedures, such as targeting total reserves, that his staff argued would better control the growth of M1. Roos also tended to dismiss claims that deregulation and financial innovation had made M1 unreliable or disconnected from inflation and real activity. The views Roos represented were not those of a practical monetarist, but rather those of a purist.

Whether the economic cost of reducing the rate of inflation would have been lower if the Fed had followed monetarist orthodoxy rather than Volcker's pragmatic approach is unknow- 


\section{Figure 5}

\section{Ex-Post Real Interest Rates, 1973 to 1983}

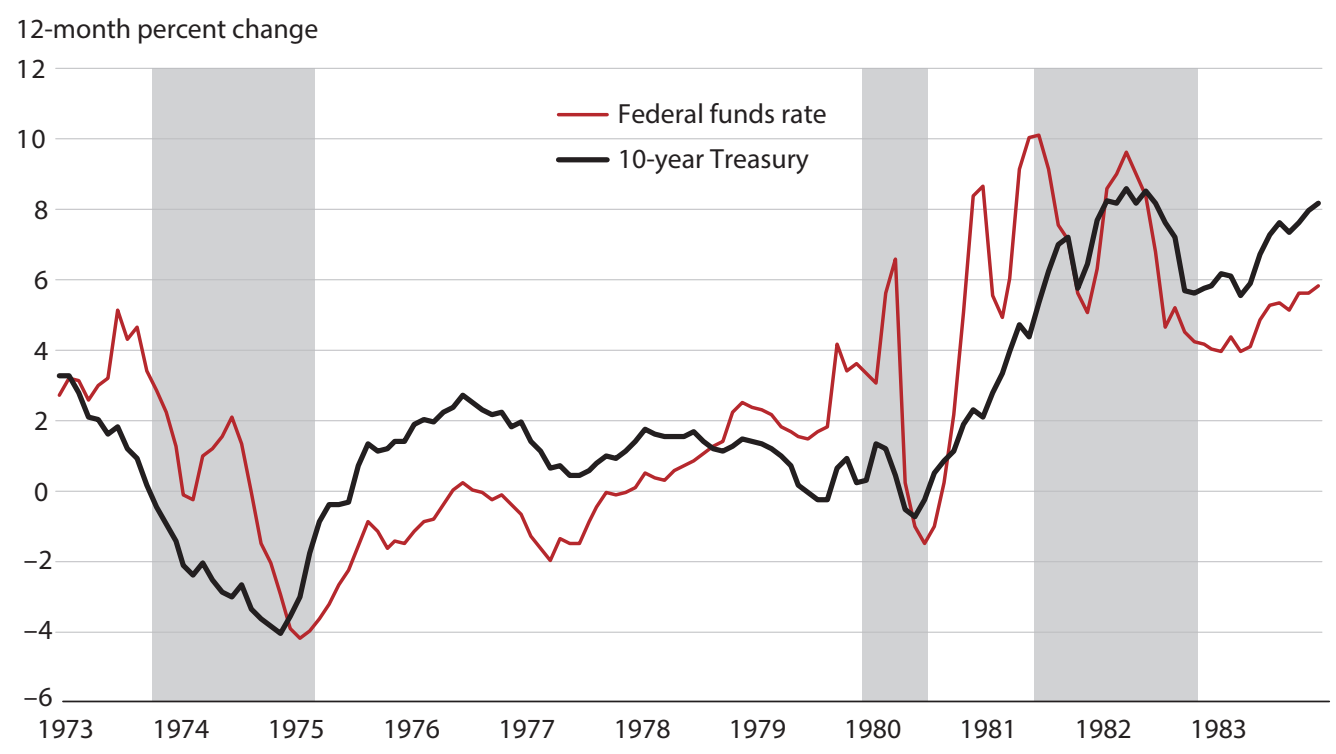

NOTE: Gray bars indicate recessions as determined by the National Bureau of Economic Research. SOURCE: Haver Analytics.

able. Inflation, as measured by the 12 -month percentage change in the all-items CPI, did fall dramatically. After reaching a (then) post-WWII high of 12.2 percent in November 1974, inflation eventually soared even higher, reaching 14.6 percent in March and April 1980. By July 1983, CPI inflation had declined to 2.4 percent (see Figure 1). As Figure 5 shows, however, ex-post short- and long-term real interest rates remained high for several years, suggesting that some doubts about the Fed's commitment to price stability remained. However, when Volcker decided to abandon monetary aggregate targeting in 1982, he did not abandon his commitment to price stability. That central tenant of monetarism remained a key aspect of the policy regime that helped set the stage for the Great Moderation. $\frac{.1}{}$ In adopting new operating procedures in 1979, Volcker demonstrated how a change in operating procedures could help change policy fundamentally, whereas in 1982, he showed that it was possible to adapt methods to changed circumstances without abandoning the foundational aspect of the policy regime.

Unlike Paul Volcker, Lawrence Roos was not an economist. His only formal training in economics came from his research director, Ted Balbach, and the staff economists who briefed him. It seems apparent from the transcripts that Roos was a quick study, however, or, at least, that he accepted and could effectively communicate the views of his staff in a cogent fashion. Those views, which reflected long-held positions of St. Louis Fed presidents and staff, were that inflation was too high and caused principally by poor monetary policy and that controlling the growth of the money supply was the only recipe for ending the Great Inflation. Fundamentally, those were also the views of Paul Volcker. 


\section{Kliesen and Wheelock}

\section{NOTES}

1 Board of Governors of the Federal Reserve System (2019).

$\underline{2}$ Hetzel (2008) and Meltzer (2009) are leading examples.

3 Volcker (2008-10 interview, p. 75).

4 Balbach $(2002$, p. 8$)$.

$\underline{5}$ Roos was a banker and St. Louis County Executive before his appointment to the St. Louis Fed (Federal Reserve History, n.d.). Jack Tatom, who was a St. Louis Fed staff economist at the time, recalls that Roos "was very good at absorbing what he was told [by the staff] and presenting it well, even in nuanced discussions with professionals. When he came upon something he did not know or did not understand he invited staff to explain and at a level he could follow. He was not shy about freewheeling when he had to be" (correspondence with the authors, June 4, 2020).

6 See articles in the Financial Times (Greely, Fleming, Lascalles, 2019) and the New York Times (Applebaum and Hershey, 2019) and John Taylor's (2019) op-ed in the Wall Street Journal.

$\underline{7}$ See Hakkio (2013) and the references therein.

8 The Great Moderation commonly refers to the period of low, stable inflation, and limited business cycle fluctuations from the mid-1980s until the Financial Crisis of 2007-09.

9 In November 2018, the FOMC announced a review of its monetary policy strategy, tools, and communications that were expected to be completed in mid-2020. See https://www.federalreserve.gov/monetarypolicy/ review-of-monetary-policy-strategy-tools-and-communications.htm for an overview.

10 See Bordo and Orphanides (2013) for perspectives on the Great Inflation.

11 The previous high for CPI inflation was 17.6 percent in June 1947. Although seasonally adjusted CPI data begin in January 1947, not seasonally adjusted CPI data begin in January 1921. Using 12-month percent change allows comparability between seasonally adjusted and not seasonally adjusted data.

12 Maisel (1973, p. 12)

13 Volcker (2008-10 interview, p. 93)

14 See Feldstein (2013, p. 107).

15 The presidents and economists of the Federal Reserve Banks of Atlanta and Richmond at times also advocated for monetarist-oriented policies. See discussions in Hafer (1999), Hafer and Wheelock (2001, 2003), Hetzel (2008) and Meltzer (2009).

$\underline{16} \operatorname{Roos}(1978$, p. 5).

17 William Poole (1979, p. 484).

$\underline{18}$ Volcker (2008-10 interview, p. 78)

19 See Volcker (1976 and 2018).

20 See Greider (1987) or Hetzel (2008, pp. 152-53).

21 Volcker (2008-10 interview, p. 87)

$\underline{22}$ Volcker (2008-10 interview, p. 73)

$\underline{23}$ Congress formally required the Fed to announce annual targets for money growth in an amendment to the Federal Reserve Act in 1977 and again in the Humphrey-Hawkins Act of 1978.

$\underline{24}$ FOMC Transcript (October 6, 1979, p. 8).

$\underline{25}$ Quoted in Lang (1980, p. 12).

$\underline{26}$ Lang (1980, p. 16). See Lang (1980), Lindsey (1986), or Hetzel (2008, pp. 166-71) for more details about the new operating procedures. 
27 Meltzer (2009, p. 1034).

$\underline{28}$ Friedman (1963, p. 16).

29 Meltzer (2009, p. 1034), quoting a 1980 Volcker speech.

30 Meltzer (2009, p. 1010), quoting a 1977 Federal Reserve Bank of New York document.

31 Meltzer (2009, p. 1014), quoting Volcker's testimony before the Senate Banking Committee in 1979.

32 Volcker knew he could count on support from St. Louis: "I knew that there would be some sympathy for the new operating procedures from St. Louis and Boston" (Volcker, 2008-10 interview, p. 75).

33 Quoted in Lindsey, Orphanides, and Rasche (2005, p. 202).

34 Quoted in Lindsey, Orphanides, and Rasche (2005, p. 203).

35 Quoted in Lindsey, Orphanides, and Rasche (2005, p. 204).

36 Quoted in Lindsey, Orphanides, and Rasche (2005, p. 206).

37 Roos (1979, pp. 5-6).

$\underline{38}$ Volcker (1979, p. 4).

39 Volcker (1979, p. 2).

$\underline{40}$ Roos (1980a, pp. 3-5)

$\underline{41}$ FOMC Transcript (May 20, 1980, p. 23).

$\underline{42}$ FOMC Transcript (May 20, 1980, p. 28).

$\underline{43}$ FOMC Transcript (October 21, 1980, p. 40).

44 FOMC Transcript (May 20, 1980, p. 42).

$\underline{45} \operatorname{Roos}(1980$ b, pp. 3, 4, and 6).

$\underline{46} \operatorname{Roos}(1980$ c, p. 5).

$\underline{47}$ Greider (1987) details numerous accounts_including Congressional testimony —of individuals and business owners who believed they were adversely affected by the Fed's new operating procedures that, in their view, triggered the double-dip recessions of the early 1980s. See in particular Chapter 12.

$\underline{48}$ In an analysis of the Volcker disinflation, Goodfriend and King (2005) argued that output losses were magnified because the Fed's regime change was not viewed as credible "for several years." Bernanke, Gertler, and Watson (1997) find that shocks to monetary policy explain less than 20 percent of the variation in real GDP. However, since most recessions are preceded by an oil shock, they argue that the Fed's role in the business cycle is amplified because of its response to oil price shocks.

49 See https://fred.stlouisfed.org/series/WTISPLC, monthly averages of daily data. Prior to 1982, West Texas Intermediate crude oil used the "posted price," which was effectively determined by the allowable production levels set by the Texas Railroad Commission and other state regulatory agencies.

$\underline{50}$ Volcker (2008-10 interview, pp. 135 and 139).

51 Quoted in Hetzel (2008, p. 157). In the St. Louis Fed's annual review of monetary policy over the preceding calendar year, Gilbert and Trebing (1981) concluded that credit controls contributed to turbulence in the economy and hampered the conduct of monetary policy by reducing demand for credit by more than anticipated.

$\underline{52}$ We focus almost exclusively on M1, as it was the FOMC's primary monetary target during 1979-82. The data plotted in Figure 3 use the current definition of M1, rather than the definition cited in Table 1.

$\underline{53}$ Roos (1981a, pp. 5 and 7). St. Louis Fed economists concluded that money supply growth exceeded the FOMC's targets in the second half of 1980 because the Committee did not follow its stated policy rather than because of flaws with the operating procedures (Gilbert and Trebing, 1981).

$\underline{54}$ Volcker (1981a, pp. 1 and 4). 


\section{Kliesen and Wheelock}

$\underline{55}$ Volcker (1981a, pp. 6-7).

$\underline{56}$ Roos (1981b, pp. 3-4, 5, 7). Roos's argument for using total reserves or the monetary base, rather than nonborrowed reserves, as the Fed's operating target was supported by St. Louis Fed research, for example, Thornton (1982b).

$\underline{57}$ Roos (1981c, pp. 1 and 6).

$\underline{58}$ Thornton (1982a, p. 16).

$\underline{59}$ FOMC Transcript (May 20, 1980, p. 29-30).

60 FOMC Transcript (July 9, 1980, p. 31). St. Louis Fed studies that supported Roos's view include Hafer (1981, p. 13), who argued that "The evidence.... indicates that the growth of M1B is influenced relatively less by nonpolicy activity - that is, it is easier to control-than $\mathrm{M} 2$, and... the growth of M1B better explains variations in the pace of economic activity than M2," and Batten and Thornton (1983, p. 40), who found that "the link between M1 growth and GNP growth remained strong up to the fourth quarter of 1982...Both the in-sample and out-of-sample performance of the M1 equation are considerably better than those of the M2 equation."

61 FOMC Transcript (March 29-30, 1982, pp. 35 and 51).

$\underline{62} \operatorname{Roos}(1982 a$, pp. 6 and 8)

63 FOMC Transcript (December 18-19, 1980, p. 36).

64 FOMC Transcript (July 6-7, 1981, p. 30).

65 FOMC Transcript (October 5-6, 1981, pp. 34-35).

$\underline{66}$ FOMC Transcript (November 17, 1981, p. 27).

67 FOMC Transcript (March 29-30, 1982, p. 24).

68 Seventy-two statements are available for this period in FRASER: https://fraser.stlouisfed.org/title/statements-speeches-paul-a-volcker-451?browse=1970s.

$\underline{69}$ Volcker (2008-10 interview, p. 86)

$\underline{70}$ Volcker (1981b, p. 17).

71 FOMC Transcript (March 29-30, 1982, p. 50).

72 FOMC Transcript (August 24, 1982, p. 30).

73 FOMC Transcript (August 24, 1982, p. 29).

$\underline{74}$ Volcker (1982, p. 1).

$\underline{75}$ Volcker (1982, p. 3).

$\underline{76}$ Figure 4 plots counts of the following keywords spoken by Roos and Volcker, respectively, at each FOMC meeting: money growth; aggregates; M1; M2; M3; inflation; Friedman; Milton; interest; fed funds; federal funds; and any words that include the prefix "monetar," such as monetary, monetarism, and monetarist.

$\underline{77}$ FOMC Transcript (October 5, 1979, p. 12).

78 FOMC Transcript (October 5, 1982, p. 48).

$\underline{79}$ FOMC Transcript (October 5, 1982, p. 48).

$\underline{80}$ FOMC Transcript (October 5, 1982, p. 50).

81 FOMC Transcript (October 5, 1982, p. 59). The November 19, 1982, Record of Policy Actions published the Directive adopted at the October 5, 1982, FOMC meeting; see https://www.federalreserve.gov/monetarypolicy/files/fomcropa19821005.pdf.

82 The framework that the FOMC adopted in October 1982 used borrowed reserves as its operating target. Thornton (1988) describes how the procedure was used for high-frequency stabilization of the federal funds rate.

$\underline{83}$ FOMC Transcript (October 5, 1982, pp. 49 and 52). 
84 FOMC (1982, p. 13).

$\underline{85} \operatorname{Roos}(1982 a$, pp. 3 and 6-8).

86 FOMC Transcript (November 16, 1982, p. 45).

87 FOMC Transcript (November 16, 1982, p. 45).

88 The FOMC formally announced its 2 percent objective for inflation in the following statement of long-run goals and monetary policy strategy issued in 2012: https://www.federalreserve.gov/monetarypolicy/files/FOMC LongerRunGoals.pdf.

$\underline{89}$ For example, see Federal Reserve Chair Jerome Powell's (2019) opening remarks at the Federal Reserve's June 4, 2019, event, "Conference on Monetary Policy Strategy, Tools, and Communications Practices."

90 Board of Governors of the Federal Reserve System (2020).

91 In this vein, see Greenspan (2004) and Bernanke (2004) and references therein.

\section{REFERENCES}

Applebaum, Binyamin and Hershey. "Paul A. Volcker, Fed Chairman Who Wages War on Inflation, Is Dead at $92 . "$ New York Times, December 9, 2019 (Updated December, 13, 2019); https://www.nytimes.com/2019/12/09/business/paul-a-volcker-dead.html.

Balbach, Anatol B. "How Controllable is Money Growth?" Federal Reserve Bank of St. Louis Review, April 1981, pp. 3-12; https://research.stlouisfed.org/publications/review/1981/04/01/how-controllable-is-money-growth.

Balbach, Anatol (Ted) B. Interview by Robert Hetzel. Transcript, May 12, 2002; https://fraser.stlouisfed.org/files/docs/historical/hetzel interviews/balbach t 20020512.pdf.

Batten, Dallas S. and Thornton, Daniel L. "M1 or M2: Which Is the Better Monetary Target?" Federal Reserve Bank of St. Louis Review, June/July 1983, 65(6), pp. 36-42; https://doi.org/10.20955/r.65.36-42.aeq.

Bernanke, Ben S. "The Great Moderation." Remarks at the meetings of the Eastern Economic Association, Washington, DC, February 20, 2004; https://www.federalreserve.gov/boarddocs/speeches/2004/20040220/.

Bernanke, Ben S.; Gertler, Mark and Watson, Mark. "Systematic Monetary Policy and the Effects of Oil Price Shocks." Brookings Papers on Economic Activity, 1997, 28(1), pp. 91-157; https://doi.org/10.2307/2534702.

Board of Governors of the Federal Reserve System. "Statement from Chair Powell on the Death of Paul Volcker." Press release, December 19, 2019; https://www.federalreserve.gov/newsevents/pressreleases/other20191209a.htm.

Board of Governors of the Federal Reserve System. "Statement on Longer-Run Goals and Monetary Policy." August 27, 2020; https://www.federalreserve.gov/monetarypolicy/files/FOMC LongerRunGoals.pdf.

Bordo, Michael D. and Orphanides, Athanasios, eds. The Great Inflation: The Rebirth of Modern Central Banking. University of Chicago Press, 2013.

Federal Open Market Committee. Transcripts. Various meetings.

Federal Open Market Committee. Press Release. November 19, 1982; https://www.federalreserve.gov/monetarypolicy/files/fomcropa19821005.pdf.

Federal Reserve History. "Lawrence K. Roos." https://www.federalreservehistory.org/people/lawrence k roos, accessed July 9, 2020.

Feldstein, Martin. "An Interview with Paul Volcker." Journal of Economic Perspectives, Fall 2013, 27(4), pp. 105-20; https://doi.org/10.1257/jep.27.4.105.

Friedman, Milton. Inflation: Causes and Consequences. Asia Publishing House for the Council for Economic Education, February 1963. Reprinted in Dollars and Deficits: Inflation, Monetary Policy and the Balance of Payments by Milton Friedman. Prentice-Hall, 1968, pp. 21-46.

Gilbert, R. Alton and Trebing, Michael E. "The FOMC in 1980: A Year of Reserve Targeting." Federal Reserve Bank of 


\section{Kliesen and Wheelock}

St. Louis Review, August/September 1981, pp. 2-22; https://doi.org/10.20955/r.63.2-22.uxg.

Goodfriend, Marvin and King, Robert G. "The Incredible Volcker Disinflation." Journal of Monetary Economics, July 2005, 52(5), pp. 981-1015; https://doi.org/10.1016/j.jmoneco.2005.07.001.

Greely, Brendan; Fleming, Sam and Lascelles, David. "Central Bankers Pay Tribute to Paul Volcker." Financial Times, December 9, 2019; https://www.ft.com/content/9207ec82-1a8c-11ea-97df-cc63de1d73f4.

Greenspan, Alan. "Risk and Uncertainty in Monetary Policy." American Economic Review, May 2004 (Papers and Proceeding), 94(2), pp. 33-40; https://doi.org/10.1257/0002828041301551.

Greider, William. Secrets of the Temple: How the Federal Reserve Runs the Country. Simon and Schuster, 1987.

Hafer, R.W. "Much Ado about M2." Federal Reserve Bank of St. Louis Review, October 1981, pp. 13-18; https://doi.org/10.20955/r.63.13-18.vol.

Hafer, R.W. "Against the Tide: Malcolm Bryan and the Introduction of Monetary Aggregate Targets." Federal Reserve Bank of Atlanta Economic Review, First Quarter 1999, 84(1), pp. 20-37;

https://www.frbatlanta.org/research/publications/economic-review/1999/q1/vol84no1 introduction-of-monetary-aggregate-targets.

Hafer, R.W. and Wheelock, David C. "The Rise and Fall of a Policy Rule: Monetarism at the St. Louis Fed, 1968-1986." Federal Reserve Bank of St. Louis Review, January/February 2001, pp. 1-24; https://doi.org/10.20955/r.83.1-24.

Hafer, R.W. and Wheelock, David C. "Darryl Francis and the Making of Monetary Policy, 1966-1975." Federal Reserve Bank of St. Louis Review, March/April 2003, pp. 1-12; https://doi.org/10.3886/ICPSR01283.

Hakkio, Craig S. "The Great Moderation." Federal Reserve History, November 22, 2013; https://www.federalreservehistory.org/essays/great_moderation.

Hamilton, James D. "Historical Oil Shocks." Manuscript, February 1, 2011. https://econweb.ucsd.edu/ jhamilto/oil_history.pdf.

Hetzel, Robert L. The Monetary Policy of the Federal Reserve: A History. Cambridge University Press, 2008; https://doi.org/10.1017/CBO9780511754173.

Lang, Richard W. "The FOMC in 1979: Introducing Reserve Targeting." Federal Reserve Bank of St. Louis Review, March 1980, pp. 2-25; https://doi.org/10.20955/r.62.2-25.wzr.

Lindsey, David E. "The Monetary Regime of the Federal Reserve System," in Colin D. Campbell and William R. Dougan, eds., Alternative Monetary Regimes. Johns Hopkins University Press, 1986, pp. 168-208.

Lindsey, David E.; Orphanides, Athanasios and Rasche, Robert H. "The Reform of October 1979: How It Happened and Why." Federal Reserve Bank of St. Louis Review, March/April 2005 (Part 2), 87(2), pp. 187-235; https://doi.org/10.20955/r.87.187-236.

Maisel, Sherman J. Managing the Dollar. W.W. Norton, 1973.

Meltzer, Allan H. A History of the Federal Reserve, Volume 2, Book 2, 1970-1986. University of Chicago Press, 2009; https://doi.org/10.7208/chicago/9780226519968.001.0001.

Poole, William. "Burnsian Monetary Policy: Eight Years of Progress?" Journal of Finance, May 1979 (Papers and Proceedings of the 37th Annual Meeting), 34(2), pp. 473-84; https://doi.org/10.1111/j.1540-6261.1979.tb02111.x.

Powell, Jerome H. "Opening Remarks." Address before the Conference on Monetary Policy Strategy, Tools, and Communications Practices sponsored by the Federal Reserve System at the Federal Reserve Bank of Chicago, June 4, 2016; https://fraser.stlouisfed.org/title/1164/item/585958.

Roos, Lawrence K. "Inflation: Truths and Half-Truths." Address before the Regional Conference of National Association of Business Economists, April 26, 1978; https://fraser.stlouisfed.org/files/docs/historical/frbsl_history/presidents/roos/Roos 19780426.pdf.

Roos, Lawrence K. "The New Fed Policy." Address before the Economic Conference on Monetary Policy sponsored by the Federal Reserve Bank of St. Louis and the Center for the Study of American Business, Washington University, St. Louis, MO, October 19, 1979; https://fraser.stlouisfed.org/title/482/item/18681. 
Roos, Lawrence K. "Address before the Kansas City Society of Financial Analysts, Kansas City, Missouri." February 19, 1980a; https://fraser.stlouisfed.org/title/482/item/18683.

Roos, Lawrence K. "The Need for Clear Thinking in Dealing with Inflation." Address before the Traffic Club of St. Louis, April 15, 1980b; https://fraser.stlouisfed.org/title/482/item/18684.

Roos, Lawrence K. "An Inflation Generation." Federal Reserve Bank of St. Louis Review, May 1980c, pp. 3-6; https://research.stlouisfed.org/publications/review/1980/05/01/an-inflation-generation.

Roos, Lawrence K. "Why Can't the Federal Reserve Control Interest Rates?" Address before the Third Annual Business Forecast Conference, Chapman College, Orange, CA, January 16, 1981a; https://fraser.stlouisfed.org/title/482/item/18688.

Roos, Lawrence K. "Monetary Policy in 1980...A Disappointing Year." Address before the New York Society of Securities Analysts, New York, NY, March 19, 1981b; https://fraser.stlouisfed.org/title/482/item/18689.

Roos, Lawrence K. "Monetary Policy... A Time for Resolve, Not Retreat." Address before the Institutional Investor Bond Conference, New York, NY, October 15, 1981c; https://fraser.stlouisfed.org/title/482/item/18691.

Roos, Lawrence K. "Does Money Still Matter?" Address before the New York Society of Security Analysts, New York, NY, October 6, 1982a; https://fraser.stlouisfed.org/title/482/item/18697.

Roos, Lawrence K. "What We Can Learn From the Past." Address before the Economic Club of Pittsburgh, Pittsburgh, PA, November 9, 1982b; https://fraser.stlouisfed.org/title/482/item/18698.

Taylor, John B. “Paul Volcker Was Inflation's Worst Enemy" (op-ed). Wall Street Journal, December 9, 2019; https://www.wsj.com/articles/paul-volcker-was-inflations-worst-enemy-11575937617.

Thornton, Daniel L. "The FOMC in 1981: Monetary Control in a Changing Financial Environment." Federal Reserve Bank of St. Louis Review, April 1982a, pp. 3-22; https://doi.org/10.20955/r.64.3-22.jej.

Thornton, Daniel L. "Simple Analytics of the Money Supply Process and Monetary Control." Federal Reserve Bank of St. Louis Review, October 1982b, pp. 22-39; https://doi.org/10.20955/r.64.22-39.mmx.

Thornton, Daniel L. "The Borrowed-Reserves Operating Procedure: Theory and Evidence." Federal Reserve Bank of St. Louis Review, January/February 1988, 70(1); https://doi.org/10.20955/r.70.30-54.phh.

Volcker, Paul A. "The Contributions and Limitations of Monetary Analysis." Address before the Joint Luncheon of the American Economic Association and the American Finance Association, September 16, 1976. Reprinted in the Federal Reserve Bank of New York Quarterly Review, May 1989 (Special Issue: 75th Anniversary), pp. 38-44; https://www.newyorkfed.org/medialibrary/media/aboutthefed/Speciallssue75thAnniversary.pdf.

Volcker, Paul A. "A Time of Testing." Remarks before the American Bankers Association, New Orleans, LA, October 9, 1979; https://fraser.stlouisfed.org/title/451/item/8203.

Volcker, Paul A. "Remarks Before the Annual Meeting of the American Farm Bureau Federation, New Orleans, Louisiana." January 12, 1981a; https://fraser.stlouisfed.org/title/451/item/8230.

Volcker, Paul A. Interview by Sam Donaldson. ABC News Issues and Answers, August 30, 1981b; https://fraser.stlouisfed.org/title/451/item/8241.

Volcker, Paul A. "Excerpt from Informal Talk to Business Council at Hot Springs, VA." October 9, 1982; https://fraser.stlouisfed.org/title/451/item/8264.

Volcker, Paul A. Interview. Federal Reserve Board Oral History Project. Transcript, 2008-10: February 25, 2008; January 28, 2008; July 22, 2008; July 28, 2008; October 23, 2008; October 24, 2008; December 29, 2009; and March 24, 2010; https://www.federalreserve.gov/aboutthefed/files/paul-a-volcker-interview-20080225.pdf.

Volcker, Paul A. Keeping At It: The Quest for Sound Money and Good Government (with Christine Harper). Public Affairs, Hatchette Book Group, 2018. 
